\title{
Proximate Composition of Whole Seeds and Pulp of African Black Velvet Tamarind (Dialium guineense)
}

\author{
Folake G. Osanaiye ${ }^{1,2}$, Mutiu A. Alabi* ${ }^{2}$, Rita M. Sunday ${ }^{1,3}$, Temitope Olowokere $^{2}$, \\ Ekundayo T. Salami ${ }^{2}$, Taiwo A. Otunla ${ }^{2}$ and Stella C. Odiaka ${ }^{2}$ \\ ${ }^{I}$ Biology Department, Faculty of Science, University of Abuja, Abuja, Nigeria \\ ${ }^{2}$ Molecular Biology/Bioinformatics Unit, Bioresources Development Centre, National Biotechnology \\ Development Agency, Ogbomosho, Nigeria \\ ${ }^{3}$ Pharmacology Department, Faculty of Pharmacy, Obafemi Awolowo Univeristy, Ile-Ife, Nigeria
}

\begin{abstract}
Whole seeds and pulp of Dialium guineense have been used as medicinal remedies, as source of vitamin $C$ and as flavour in snacks and non alcoholic beverages but not much work has been done on its proximate composition. This study is aimed at analysing the proximate composition of Dialium guineense. The method applied in this analytical determination were mainly that of the association of official analytical chemist (AOAC) which includes spectrophotometer, gravimetric and titrimetric and all determination were carried out in duplicate. Values obtained for the proximate analysis of whole seeds and pulp were; moisture $110.13 \%$ and $10.53 \%)$, dry matter (90.15\% and $88.4 \%)$, ash (2.55\% and $12.52 \%)$, organic matter $(12.62 \%$ and $41.55 \%)$, crude fat $(35.33 \%$ and $5.34 \%)$, crude fibre (13.52\% and $1.05 \%)$, carbohydrate $(43.9 \%$ and $58.65 \%)$, protein $(17.44 \%$ and $3.94 \%)$ and total nitrogen free extract $(2.79 \%$ and $0.65 \%)$ respectively. The results obtained from the proximate mineral composition of the whole seeds and pulp were; magnesium $(0.16 \mathrm{mg} / \mathrm{l}$ and $0.40 \mathrm{mg} / \mathrm{l})$, sodium $(2.42 \mathrm{mg} / \mathrm{l}$ and $2.88 \mathrm{mg} / \mathrm{l})$, iron $(0.91 \mathrm{mg} / \mathrm{l}$ and $1.43 \mathrm{mg} / \mathrm{l})$, calcium $(0.54 \mathrm{mg} / \mathrm{l}$ and $0.35 \mathrm{mg} / \mathrm{l})$ and potassium $(0.34 \mathrm{mg} / \mathrm{l}$ and $1.21 \mathrm{mg} / \mathrm{l})$ respectively. Values are significantly different from each other at $P<0.05$. The results suggest that the whole seeds and pulp of D. guineense can serve as a good source of essential nutrients for human and livestock.
\end{abstract}

Keywords: Dialium guineense, proximate analysis, minerals, nutrients, pulp, whole seed.

\section{Introduction}

Dialium guineense commonly known as African black velvet tamarind, is a large tree found in many parts of Africa such as West Africa, Central African Republic and the Chad. The tree belongs to the family Fabaceae-caesalpinioidaea, it is 30 meters high, with a densely leafy crown, but often shrubby. The leaves are finely hairy, broadly elliptic, blunt at the apex, leathery and are a sunken midrib. Its flowers appear whitish and the branches are horizontally spread [1]. Fruits are usually circular and flattened, black in colour with stalk $6 \mathrm{~mm}$ long, a little collar is seen near the apex and a bristle shell encloses one or two seeds embedded in a dry, brownish edible pulp [2]. Wild fruits are dietary supplement for rural dwellers in Nigeria during the dry season when fruits are scarce [3]. The fruits are used in medicinal remedies, as source of vitamin C, as flavour in snacks and non alcoholic beverages $[4,5]$. Fruit pulps supplies high amount of micronutrients like sodium, magnesium and potassium. Bark and leaves are used against several diseases such as malaria [6]. The pulp of tamarindus indica can be soaked in water to prepare drink to heal dysentery and stomach upset. The pulp is a source of Vitamin C which is needed by both adult and children. The leaves can be squeezed and apply on wounds, this is practiced by wolofs of Senegal [7]. Okegbile et al. [8] found high content of vitamin C and other micronutrients in wild fruits when compared with nutrition supplied by other fruits such as oranges, Avogadro pear, pineapple, pawpaw and commercially produced fruits. The thirst quenching, refreshing fruit pulp can also be soaked in water and drink as a beverage and also provides chewing sticks, jams and jellies [9]. The crude lipid contains mainly triacylglycerol, free fatty acid and sterols [8]. In a review of the nutritive values of velvet tamarind in West Africa, Le Houerou [10] concluded that velvet tamarind contains double the amount of calories of dry grasses owing to its lower content of fibre. There is less data available in the literature on the mineral concentration of velvet tamarind. The aim of this study therefore is to evaluate the potential proximate composition of whole seeds and pulp of Dialium guineense considering its wide spread use as diet for humans and live stock.

\section{Collections of Sample}

\section{Materials And Methods}

The fruits of $D$. guineense were bought at Gwagwalada FCT-Abuja main market between August and September 2008 as authenticated by Professor Olorode of Biological Science Department of the University of Abuja, Nigeria. 


\section{Sample Preparation}

The fruits were divided into two halves. One-half was set for drying under the sun to separate the pulp from the seed. This was done to obtain a powdery form of the pulp, since it was wet, while the other was soaked in tap water for about 20-30 minutes to wash off the pulp to obtain clean, pulp free whole seed. The whole seed were also sun dried, after sun drying, the whole seed and pulp were separately grounded into fine powder, using a pestle and mortar, after grinding the powder was sieved into a finer particle. The powder was then collected and stored in a well-labelled bottle with cap tightly screwed. The sample was grounded into powder before analysis to provide a larger surface area for reaction with the reagent and to ensure homogeneity.

\section{Extraction Procedure and Methods of Analysis}

The extraction procedure and methods of analysis were that of the Association of Official Analytical chemist [11]. These were mainly spectrophotometer, gravimetric and titrimetric methods.

\section{Statistical Analysis}

All the results were expressed as mean \pm SEM (Standard Error of mean) for four replicates. The data were statistically evaluated with t-test using SPSS/15 software. $P$ values $<0.05$ were considered to indicate statistical significance.

\section{Results}

Table 1: Result of proximate analysis for the whole seeds and pulp of Dialium guineense.

\begin{tabular}{|l|l|l|}
\hline Parameter in \% & Whole seed of D. guineense & Pulp of D. guineense \\
\hline Moisture & $10.13 \pm 0.012$ & $10.53 \pm 0.160$ \\
\hline Dry matter & $90.15 \pm 0.020$ & $88.40 \pm 0.001$ \\
\hline Ash & $2.55 \pm 0.007$ & $12.52 \pm 0.006$ \\
\hline Organic matter & $12.62 \pm 0.007$ & $41.55 \pm 0.004$ \\
\hline Crude fat & $35.33 \pm 0.010$ & $5.34 \pm 0.030$ \\
\hline Crude fibre & $13.52 \pm 0.360$ & $1.05 \pm 0.040$ \\
\hline Carbohydrate & $43.90 \pm 0.030$ & $58.65 \pm 0.002$ \\
\hline Protein & $17.44 \pm 0.050$ & $3.94 \pm 0.002$ \\
\hline Nitrogen & $2.79 \pm 0.080$ & $0.65 \pm 0.015$ \\
\hline
\end{tabular}

Values are Mean \pm SEM of 4 determinations. Means are significantly different from each other at $\mathrm{P}<0.05$ )

Table 1 represent the result of proximate analysis for the whole seeds and pulp of Dialium guineense. The results showed that dry matter, crude fat, crude fibre, protein and nitrogen values are statistically higher in the whole seed as compared to the pulp. The results also showed that the moisture content, ash, organic matter and carbohydrate levels to be statistically higher in the pulp as compared to the whole seed.

Table 2: Shows the proximate mineral compositions in milligram per litre of the whole seeds and pulp of Dialium guineense.

\begin{tabular}{|l|l|l|}
\hline Parameter in mg/l & Whole seed of $\boldsymbol{D}$. guineense & Pulp of D. guineense \\
\hline Magnesium & $0.16 \pm 0.060$ & $0.40 \pm 0.002$ \\
\hline Sodium & $2.42 \pm 0.004$ & $2.88 \pm 0.003$ \\
\hline Iron & $0.91 \pm 0.010$ & $1.43 \pm 0.006$ \\
\hline Calcium & $0.54 \pm 0.030$ & $0.35 \pm 0.020$ \\
\hline Potassium & $0.34 \pm 0.050$ & $1.21 \pm 0.008$ \\
\hline
\end{tabular}

Values are Mean \pm SEM of 4 determinations. Means are significantly different from each other at $(\mathrm{P}<0.05)$

Table 2 showed the proximate mineral compositions in milligram per litre of the whole seeds and pulp of Dialium guineense. The results indicate that the calcium level was significant higher in whole seed when compared with the pulp while the levels of magnesium, sodium, iron and potassium were significantly higher in the pulp when compared with whole seed.

\section{Discussion}

The proximate analysis for $D$. guineense (whole seeds and pulp), indicates that the moisture content of the whole seed was lower than that of the pulp. The moisture content obtained was $10.13 \%$. Other workers like Okegbile et al. [8] recorded $10.96 \%$ wet weight, hence it can be said that, the value obtained in this research was close to that obtained by the previous workers, while its pulp was obtained as $10.53 \%$. 
The moisture content could vary depending on the stage of ripeness of the fruit. The fruit is generally considered ripe when the pulp is dried and easily reduced to powdered form. In Nigeria, the tree flowers from September to October and brings out fruits from October to January [12], during the harmattan season. The weather could contribute to the very low moisture content of any item of food could be used as an index of stability and susceptibility to fungi infection [8].

The ash content of $D$. guineese L. Whole seed as shown in Table 1 was recorded as $2.55 \%$. This was in line with the value reported by Okegbile et al. [8] that recorded $2.86 \%$. The difference in the value could be due to time and place of collection. If the sample collected or used had been exposed to dust or dirt and other and the contaminants, this could lower the ash content and the value obtained from the pulp was $12.52 \%$ and it was found to be higher than that obtained by Attah-Krah et al. [13] which was reported as $9.7 \%$. The value of ash is useful in assessing the quality or grading certain edible material [14].

The lipids were petroleum ether extractible that is, they are soluble in ether. The value of lipid extract obtained from whole seed of Dialium guineense was found to be $35.33 \%$ dry weight which was close to the value reported by Okegbile et al. [8] which was $37.14 \%$ dry weight while the lipid content of its pulp was found to be $5.34 \%$. According to Suttie [15], a high lipid content is usually achieved at the expense of water in the cell that is; the amount of lipid in plant tissue is to some extent inversely related to its metabolic activity.

The crude protein content of the whole seeds of $D$. guineense shown in Table 1 was obtained by using a conversion factor of 6.25 which converts the amount of nitrogen which was determined to a protein basis. This is because most proteins are about $16 \%$ nitrogen. The crude protein constituted $17.44 \%$ of the whole seed on dry weight basis. The value reported by Okegbile et al. [8] was $8.91 \%$ on dry weight while its pulp was obtained to be $3.94 \%$ in this research which was lower compare to the one obtained from the whole seed.

The value of carbohydrate for whole seed was found to be $43.9 \%$ while the value obtained by Okegbile et al. [8] was reported to be $23.7 \%$, while its pulp contains $58.65 \%$ of carbohydrate.

The nitrogen free extract (NFE) of whole seed and pulp of $D$. guineense recorded in table 1 has a value of $2.79 \%$ which was very low compare to that of Okegbile et al. [8] and others which was recorded $36.34 \%$ and its pulp obtained the value of $0.65 \%$ which was almost the same as the that of Attah-Krah et al. [13] which was recorded as $0.74 \%$.

The dry matter content of $D$. guineense whole seed and its pulp was found to be $90.15 \%$ and $88.4 \%$ which were lower than that of the previous workers which was recorded as $95.20 \%$ and $89.75 \%$ these values were recorded by Attah-Krah et al., [13] and Okegbile et al. [8].

The percentage of organic matter was lower than that reported by Attah-Krah et al. [13] in their studies of shrubs and fodders. Deviation could be based on a result of environmental differences [16].

According to George Mateljan Foundation [3] dietary minerals and vitamin are the chemical elements required by living organisms, other than the four elements; carbon, hydrogen, nitrogen and oxygen present in common organic molecule.

Mineral elements composition in milligram per litre $(\mathrm{mg} / \mathrm{l})$ for Dialium guineense in this study reveals that the whole seed and pulp were very rich in sodium $(\mathrm{Na})$ at $2.42 \mathrm{mg} / \mathrm{l}$ and $2.88 \mathrm{mg} / \mathrm{l}$, this also confirm the work of Adepoju [16] when he studied three locally available wild fruits in Nigeria for their proximate composition and micronutrient potentials. Potassium is more available in the pulp than the whole seeds at $1.21 \mathrm{mg} / 1 \mathrm{and} 0.34 \mathrm{mg} / \mathrm{l}$ is value found in the whole seed. According to this study the available amount of iron (Fe) in pulp is $1.43 \mathrm{mg} / 1 \mathrm{which}$ is higher than the one available in the whole seeds at $0.91 \mathrm{mg} / \mathrm{l}$. The value of Fe in this work is almost equal to that of Effiong and Udo [6]. The whole seed contains $0.16 \mathrm{mg} / 1$ of magnesium, lower than the one contained in the pulp at $0.40 \mathrm{mg} / \mathrm{l}$. Therefore, the pulp is richer in $\mathrm{Mg}$ than the seeds. The whole seed is richer in calcium than the pulp at $0.54 \mathrm{mg} / \mathrm{l}$ while the pulp is $0.35 \mathrm{mg} / \mathrm{l}$. These values deviated from those obtained by Attah-Krah et al. [13]. The deviation could be as a result of environmental influence, experimental and/or personal error. The pulp is richer in $\mathrm{Na}, \mathrm{Fe}, \mathrm{K}$, than the whole seed. This almost agrees with the findings of Effiong and Udo [6] when they studied and compare four indigenous wild fruits in South-Eastern part of Nigeria.

\section{Conclusion}

In this study, the whole seeds and pulp of Dialium guineense can serve as source of carbohydrate for man and his lives stock which was recorded to be $43.9 \%$ and $58.68 \%$. It was also found that the seeds contain high value of lipids. The pulp is richer in sodium, iron and potassium and its whole seed was found to be rich mainly in sodium. Hence, it can provide the body with sodium and vitamin $\mathrm{C}$ when it is eaten or used as feed for livestock.

\section{References}

[1]. Szolnok, T.W., 1985. Food and fruit trees of Gambia Hamburg. Federal Republic of Germany.

[2]. Hong, T.D., S. Linington and R.H. Ellis, 1996. Seed Storage Behaviour: A Compendium. Handbook for Genebanks: No. 4. International Plant Genetic Resources Instiute, Rome, Italy.

[3]. George Mateljan Foundation, 2011. Vitamin and mineral. Elevier Science. Pub. Co., pp: 1220. 
[4]. Effiong, G.S., T.O. Ibia and U.S. Udofia, 2009. Nutritive and energy value of some wild fruit species in South Eastern Nigeria, Electr. J. Env. Agric. Food Chem., 8: 917 -923.

[5]. Adame, L., 2002. Leaf absorption of mineral nutrients in carnivorous plants stimulates root nutrient uptake. New Phytologist, 155: 89 -100 .

[6]. Effiong G.S. and I.F. Udo, 2010. Nutritive values of four indigenous wild fruits in Southeastern Nigeria. Electron. J. Environ. Agric. Food Chem., 9: 1168 -1176.

[7]. Devendra, C., 1988. Forage supplements, nutritional significance and utilization for drought, meat and milk production in buffaloes. Proceeding of the 2nd World Buffalo Congress, December 12-17, 1988, New Delhi, India, pp: 409-423.

[8]. Okegbile, E.O., K.M. Aina, A.N. Soboyejo and S.O. Akapo, 1991. Studies on lipid content and fatty acid composition of Dialium guineense wild (velvet tamarind) seed. Biosci. Res. Commun., 3: 103 -109.

[9]. FAO, 2004. Calcium reguirement. Food and Agriculture Organization, Organization of the United Nations, Rome, Italy.

[10]. Le Houerou, H.N., 2005. Chemical Composition and Nutritive Value of Browse in Tropical West Africa. In: Browse in Africa, the Current States of Knowledge, Le Houerou, H.N. (Ed.). ILCA, Addis Ababa, Ethiopia.

[11]. AOAC, 2000. Official methods of official analytical chemists. Association of Official Agricultural Chemists, Arlington Virginia, USA.

[12]. Keay, R.W., 1964. Trees of Nigeria. Claredon Press, Oxford, UK.

[13]. Attah-Krah, A.N., J.E. Sumberg and Reynolds, 1986. Leguminous Folder Tree in Farming System: An Overview of Research in the Humid Zone Programme of ICCA in South Western Nigeria. Potentials of forage legumes in farming systems of sub-saharan Africa. Haque, I., S. Jutzi and P.J. Weate (Eds.). ILCA, Addis Ababa, pp: 307-329.

[14]. Joslyn M.A., 1970. Toxic Constituents of Plant Food stuffs. Acad. Press. New York, pp. 69-101

[15]. Suttie, J.E., 1972. Introduction to Biochemistry. 2nd Edn., Holt Rinehart and Winston Inc., New York, pp: 13-15.

[16]. Adepoju, O.T., 2009. Proximate composition and micronutrient potentials of three locally available wild fruits in Nigeria. Afr. J. Agric. Res., 4: $887-892$. 